\title{
s. \\ Quantification of peptide bound particles: A phage mimicking approach via site-selective immobilization on glass
}

Martin Schrader 1, *, Caroline Bobeth 1 and Franziska L. Lederer 1

1 Department of Biotechnology, Helmholtz Institute Freiberg for Resource Technology, Helmholtz Center Dresden-Rossendorf, 01328 Dresden, Germany

* Corresponding authors 
Table S1. Pipetting scheme of the fast semi-quantitative screening for peptides;

Chapter 3.2

\begin{tabular}{|c|c|c|c|c|c|c|}
\hline & 1 & 2 & 3 & 4 & 5 & 6 \\
\hline A & Glass & Glass & Glass & $\begin{array}{c}\text { FL464 } \\
\text { R/A }\end{array}$ & $\begin{array}{c}\text { FL464 } \\
\text { R/A }\end{array}$ & $\begin{array}{c}\text { FL464 } \\
\text { R/A }\end{array}$ \\
\hline B & APDMES & APDMES & APDMES & $\begin{array}{c}\text { FL464 } \\
\text { S/A }\end{array}$ & $\begin{array}{c}\text { FL464 } \\
\text { S/A }\end{array}$ & $\begin{array}{c}\text { FL464 } \\
\text { S/A }\end{array}$ \\
\hline $\mathrm{C}$ & $\begin{array}{c}\text { FL464 } \\
\text { C1+C2/A }\end{array}$ & $\begin{array}{c}\text { FL464 } \\
\text { C1+C2/A }\end{array}$ & $\begin{array}{c}\text { FL464 } \\
\text { C1+C2/A }\end{array}$ & $\begin{array}{c}\text { FL464 } \\
\text { Y/A }\end{array}$ & $\begin{array}{c}\text { FL464 } \\
\text { Y/A }\end{array}$ & $\begin{array}{c}\text { FL464 } \\
\text { Y/A }\end{array}$ \\
\hline D & $\begin{array}{c}\text { FL464 } \\
\text { C1/A }\end{array}$ & $\begin{array}{c}\text { FL464 } \\
\text { C1/A }\end{array}$ & $\begin{array}{c}\text { FL464 } \\
\text { C1/A }\end{array}$ & FL464 & FL464 & FL464 \\
\hline $\mathrm{E}$ & $\begin{array}{l}\text { FL464 } \\
\text { C2/A }\end{array}$ & $\begin{array}{l}\text { FL464 } \\
\text { C2/A }\end{array}$ & $\begin{array}{l}\text { FL464 } \\
\text { C2/A }\end{array}$ & - & - & - \\
\hline $\mathrm{F}$ & $\begin{array}{c}\text { FL464 } \\
\text { L/A }\end{array}$ & $\begin{array}{c}\text { FL464 } \\
\text { L/A }\end{array}$ & $\begin{array}{c}\text { FL464 } \\
\text { L/A }\end{array}$ & FL606 & FL606 & FL606 \\
\hline G & $\begin{array}{c}\text { FL464 } \\
\text { P/A } \\
\end{array}$ & $\begin{array}{c}\text { FL464 } \\
\text { P/A }\end{array}$ & $\begin{array}{c}\text { FL464 } \\
\text { P/A }\end{array}$ & - & - & - \\
\hline $\mathrm{H}$ & $\begin{array}{c}\text { FL464 } \\
\text { Q/A }\end{array}$ & $\begin{array}{c}\text { FL464 } \\
\text { Q/A }\end{array}$ & $\begin{array}{c}\text { FL464 } \\
\text { Q/A }\end{array}$ & p.n.s. & p.n.s. & p.n.s. \\
\hline
\end{tabular}


Table S2. Fluorescence sums of the fast semi-quantitative screening for peptides;

Chapter 3.2

\begin{tabular}{|c|c|c|c|c|c|c|}
\hline & 1 & 2 & 3 & 4 & 5 & 6 \\
\hline A & 28096 & 26848 & 25488 & 27984 & 25936 & 31040 \\
\hline B & 26088 & 26744 & 25752 & 24528 & 24744 & 26272 \\
\hline C & 26048 & 25944 & 26672 & 24112 & 24184 & 24800 \\
\hline D & 35744 & 32392 & 25320 & 25240 & 24872 & 38736 \\
\hline E & 27320 & 31792 & 37816 & - & - & - \\
\hline F & 26968 & 43328 & 37832 & 24984 & 25008 & 54296 \\
\hline G & 43664 & 40384 & 32760 & - & - & - \\
\hline H & 49192 & 25568 & 26680 & - & - & - \\
\hline
\end{tabular}


Table S3. Results of the semi-quantitative screening for peptides; Chapter 3.2

\begin{tabular}{|c|c|c|c|c|c|c|c|}
\hline Alias & $\begin{array}{c}\text { Mean } \\
\text { summed } \\
\text { fluorescence }\end{array}$ & $\begin{array}{l}\text { Relative to } \\
\text { glass }\end{array}$ & $\begin{array}{l}\text { Relative to } \\
\text { APDMES }\end{array}$ & SD & RSD & SEM & REM \\
\hline Glass & 26810.67 & 1.00 & 1.02 & 1065.04 & 3.97 & 614.90 & 2.29 \\
\hline APDMES & 26194.67 & 0.98 & 1.00 & 411.95 & 1.57 & 237.84 & 0.91 \\
\hline $\mathrm{FL} 464 \mathrm{C} 1+\mathrm{C} 2 / \mathrm{A}$ & 26221.33 & 0.98 & 1.00 & 321.49 & 1.23 & 185.61 & 0.71 \\
\hline FL464 C1/A & 31152.00 & 1.16 & 1.19 & 4344.97 & 13.95 & 2508.57 & 8.05 \\
\hline FL464 C2/A & 32309.33 & 1.21 & 1.23 & 4300.56 & 13.31 & 2482.93 & 7.68 \\
\hline FL464 L/A & 36042.67 & 1.34 & 1.38 & 6797.73 & 18.86 & 3924.67 & 10.89 \\
\hline FL464 P/A & 38936.00 & 1.45 & 1.49 & 4567.77 & 11.73 & 2637.21 & 6.77 \\
\hline FL464 Q/A & 33813.33 & 1.26 & 1.29 & 10883.83 & 32.19 & 6283.78 & 18.58 \\
\hline FL464 R/A & 28320.00 & 1.06 & 1.08 & 2097.20 & 7.41 & 1210.82 & 4.28 \\
\hline FL464 S/A & 25181.33 & 0.94 & 0.96 & 776.24 & 3.08 & 448.16 & 1.78 \\
\hline FL464 Y/A & 24365.33 & 0.91 & 0.93 & 308.76 & 1.27 & 178.26 & 0.73 \\
\hline FL464 & 29616.00 & 1.10 & 1.13 & 6450.56 & 21.78 & 3724.23 & 12.58 \\
\hline
\end{tabular}


Table S4. Results of UV-Vis absorbance measurements; Chapter 3.4

\begin{tabular}{|c|c|c|c|c|c|c|c|c|}
\hline & $0.05 \mathrm{mM}$ & REM [\%] & $0.48 \mathrm{mM}$ & REM [\%] & $0.96 \mathrm{mM}$ & REM [\%] & $1.43 \mathrm{mM}$ & REM [\%] \\
\hline FL464 & 0,397 & 2,29 & 0,390 & 3,79 & 0,400 & 3,28 & 0,416 & 1,85 \\
\hline $\mathrm{C} 1$ & 0,345 & 1,59 & 0,318 & 1,10 & 0,327 & 2,38 & 0,349 & 2,48 \\
\hline $\mathrm{C} 2$ & 0,308 & 2,73 & 0,298 & 3,01 & 0,305 & 5,12 & 0,305 & 1,99 \\
\hline $\mathrm{C} 1+\mathrm{C} 2$ & 0,288 & 2,67 & 0,275 & 1,75 & 0,278 & 1,82 & 0,293 & 7,01 \\
\hline $\mathrm{L}$ & 0,264 & 1,79 & 0,255 & 2,20 & 0,251 & 4,20 & 0,258 & 2,27 \\
\hline$P$ & 0,243 & 2,34 & 0,249 & 6,08 & 0,238 & 5,01 & 0,263 & 5,32 \\
\hline Blank & 0.233 & 4,19 & & & & & & \\
\hline
\end{tabular}

Table S5. Results of UV-Vis absorbance measurements of $0.192 \mathrm{mM}$ peptide solution, blanked against MilliQ water with $0.8 \%$ NMP and calculated extinction coefficients; Chapter 3.4

\begin{tabular}{|c|c|c|c|}
\hline & $\begin{array}{l}\text { Absorbance } \\
\text { (280 nm) }\end{array}$ & REM [\%] & $\begin{array}{c}\varepsilon \\
{\left[\mathrm{Imol}^{-1} \mathrm{~cm}^{-1}\right]}\end{array}$ \\
\hline FL464 & 0,194 & 3,75 & 468,36 \\
\hline $\mathrm{C} 1$ & 0,168 & 2,19 & 455,54 \\
\hline $\mathrm{C} 2$ & 0,166 & 0,92 & 427,56 \\
\hline $\mathrm{C} 1+\mathrm{C} 2$ & 0,209 & 2,04 & 525,37 \\
\hline $\mathrm{L}$ & 0,174 & 3,21 & 467,83 \\
\hline$P$ & 0,128 & 0,68 & 337,87 \\
\hline
\end{tabular}



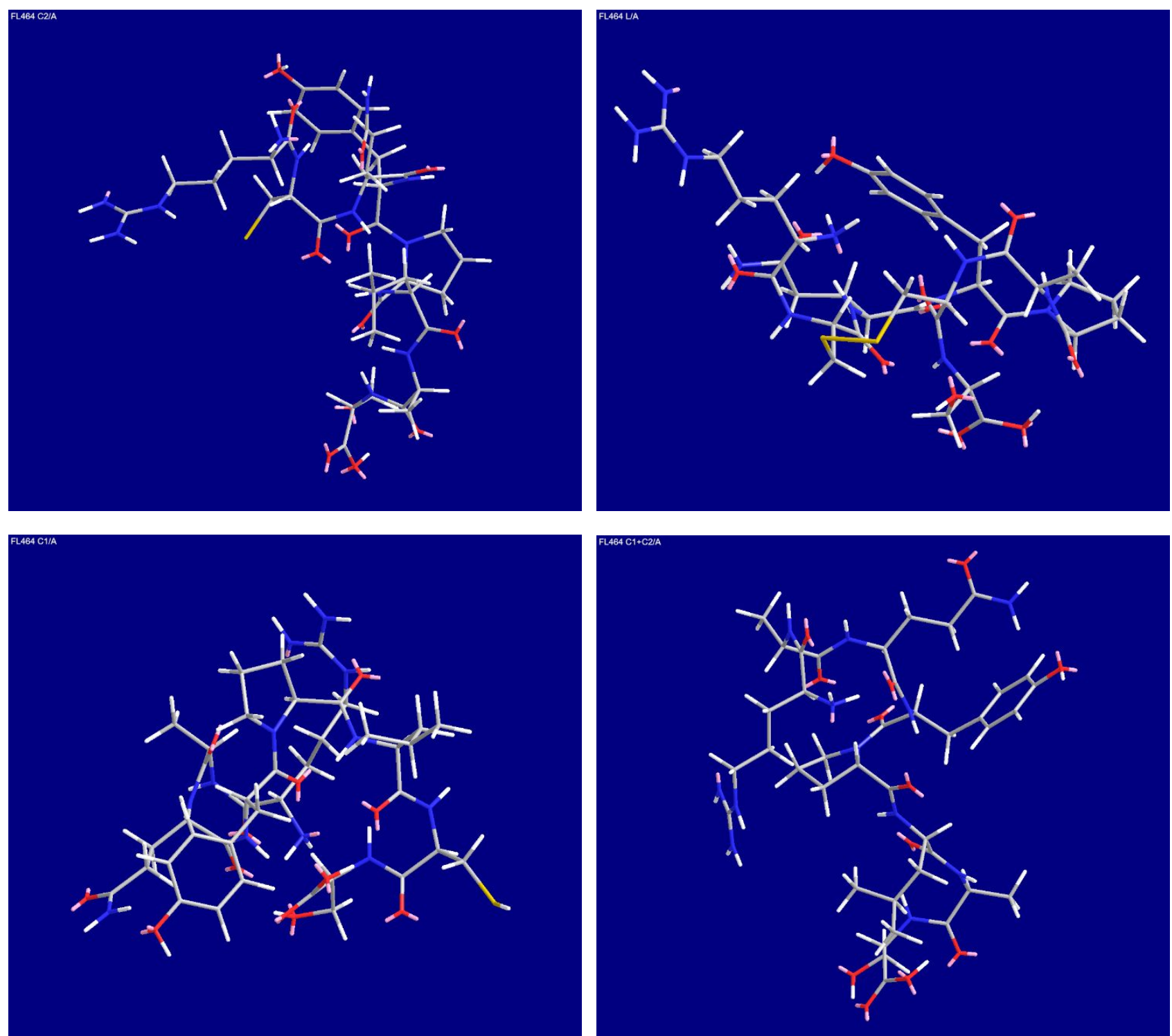

Figure S1: Image of the molecule structures after MM2 energy minimization calculations; Chapter 3.5 
Upper Left: FL464 C2/A; Upper Right: FL464 L/A; Lower Left: FL464 C1/A; Lower Right: FL464 C1+C2/A

Method 2.13 Functionalizing of microscopic slides with APDMES

For the introduction of free amino groups on the surface APDMES was used as a functional coating. Microscopic slides were cleaned with 2-propanol and MilliQ water and wiped dry with tissue before use. The area for functionalization was marked with circles on the backside of the slides. A solution of APDMES in dry THF (10 $\mu \mathrm{l} ; 0.5 \mathrm{vol}$. \%) was pipetted onto the slides and let rest and dry up for 30 min at room temperature. The slides were washed thoroughly with MilliQ water and dried overnight at $70^{\circ} \mathrm{C}$. The substrates were used directly afterwards without further cleaning.

Method 2.14 Immobilization of peptide on functionalized microscopic slides

A coupling agent solution containing $0.5 \mathrm{mM}$ PyBOP and 1.25 mM DiPEA in NMP was freshly prepared before use. Of a respective peptide solution in NMP (20 mg/ml) a volume of $1 \mu \mathrm{l}$ (approx. $17 \mathrm{nmol}, 1.0 \mathrm{eq}$ ) was pipetted onto the APDMES functionalized microscopic slides, followed by the addition of $5 \mu$ of the coupling agent solution (PyBOP: $20 \mathrm{nmol}, 1.2$ eq; DiPEA: $60 \mathrm{nmol}, 3.0$ eq) and let rest for 2 hours at room temperature. Afterwards, the slides were washed thoroughly with MilliQ water.

Results 3.6: Results of pretests on microscopic slides

Silanized microplates are not commercially available. Therefore, we decided to use microplates with a glass coating and functionalize them with APDMES to make them suitable for peptide immobilization. For this, the coating procedure was tested on commercial microscopic slides. The amount of peptide used in the experiments was only $20 \mu \mathrm{g}$ while the spreading of the droplets and therefore the immobilization area was strongly increased (diameter of $5 \mathrm{~mm}$ to ca. $10 \mathrm{~mm}$ ), thus limiting the comparability of the experiments. 
We observed a change in the wetting behavior of the coated glass compared to the non-coated areas, proving a change in the surface due to the coating. Water tends to stick to the modified spots. This effect was further enhanced after the immobilization of the peptides. The binding of the LAP particles revealed differences between the various peptides, as shown in Figure 3.

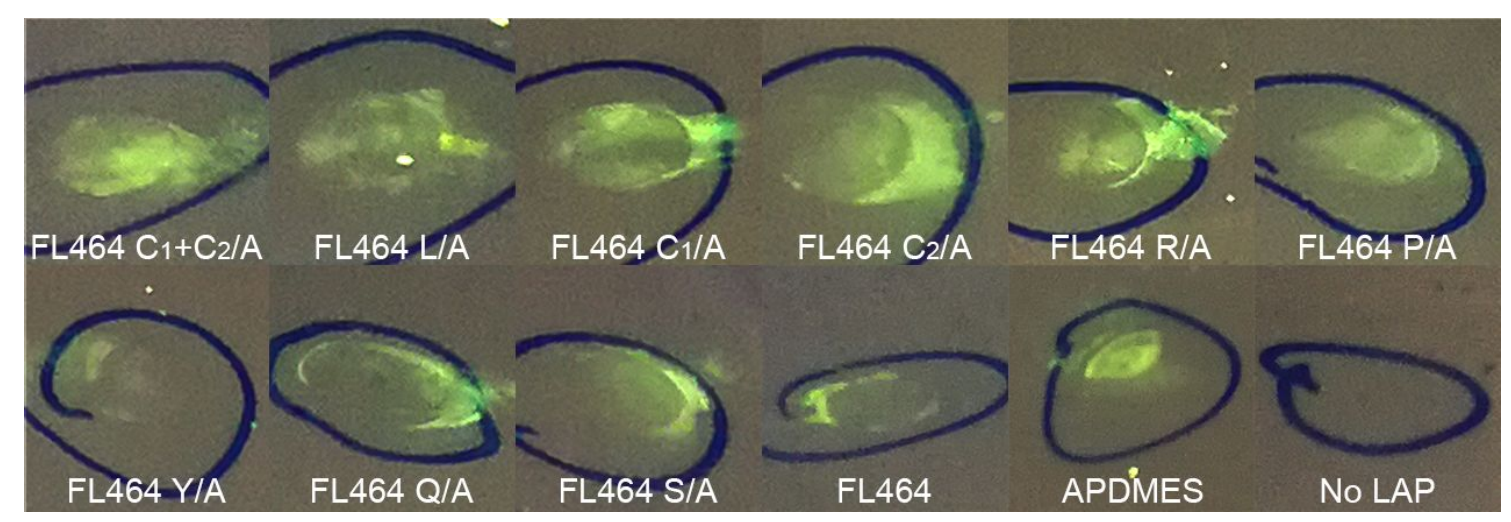

Figure S2. Selected spots on self-coated microscopic slides with LAP as bound target material. $20 \mu \mathrm{g}$ peptide were immobilized per spot. The fluorescence, $\lambda$ ex: $254 \mathrm{~nm}$ via UV-lamp, showing differences in the binding behavior of the peptides towards the target material.

On all spots, there was a distinctive border at the edge of the spot where the immobilization was performed, although LAP was also bound on plain glass and the blank coating outside the immobilization region. Especially FL464 C1+C2/A showed the highest and even spread adhesion. While most other peptides showed good adhesion of LAP as well, the peptides FL464 R/A, FL464 Y/A showed only little adhesion. In contrast to the prior experiment, FL464 bound identified peptide, performed similar to FL464. 

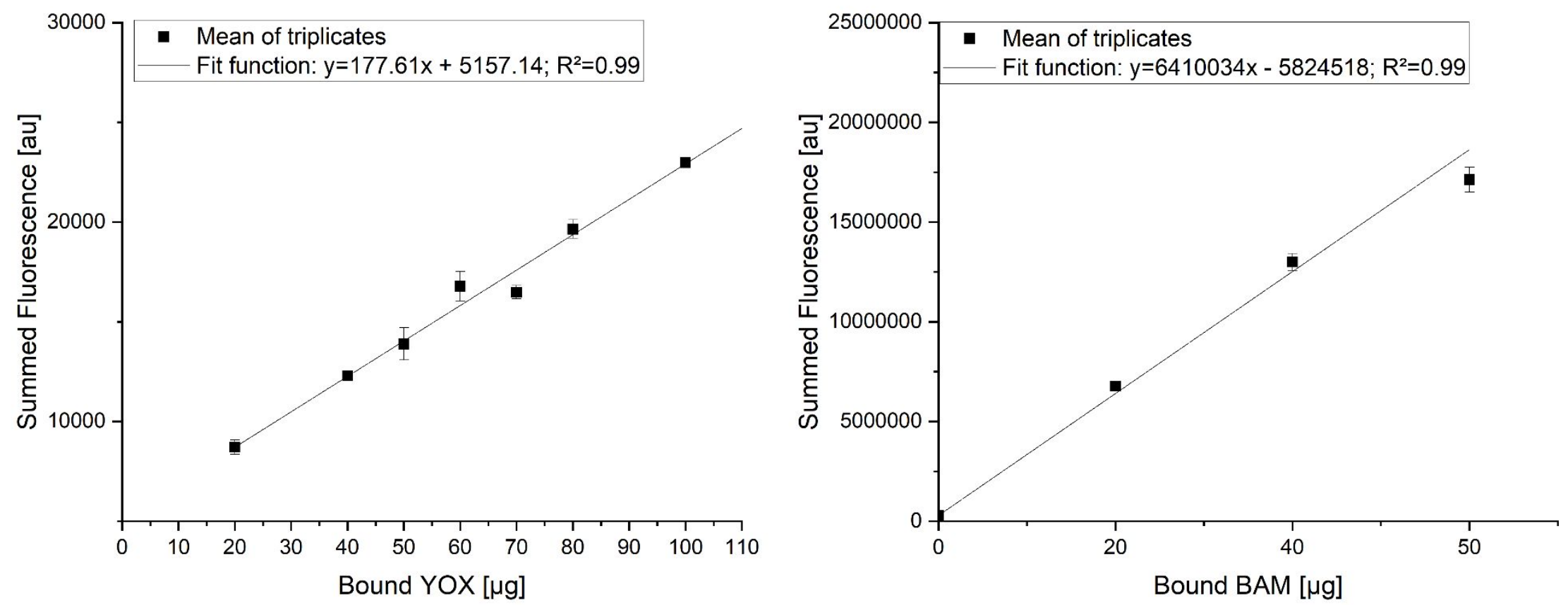

Figure S3: Calibration curve with the summed fluorescence for YOX (left) and BAM (right). The equation of the linear fit function are written in the legend of the graphs. Wavelengths used: BAM: Em 340 nm, Ex 450 nm; YOX: Em 365 nm, Ex. 545 nm.

Table S6: Used results of the calibration curve experiments for YOX and BAM. Wavelengths used: BAM: Em 340 nm, Ex 450 nm; YOX: Em $365 \mathrm{~nm}$, Ex. $545 \mathrm{~nm}$.

\begin{tabular}{c|ccc|ccc}
$\begin{array}{c}\text { Particle } \\
\text { type }\end{array}$ & BAM & & & & \\
& & & & & & \\
& Mean summed & Standard & Standard & Mean summed & Standard & Standard \\
Mass & fluorescence & deviation & error & fluorescence & deviation & error \\
\hline
\end{tabular}




\begin{tabular}{|c|c|c|c|c|c|c|}
\hline 0 & 289629 & 10173 & 5873 & - & - & - \\
\hline 20 & 6773365 & 426857 & 246446 & 8718 & 626 & 361 \\
\hline 40 & 12999989 & 736677 & 425321 & 12299 & 192 & 111 \\
\hline 50 & 17127562 & 1089923 & 629268 & 13888 & 1394 & 805 \\
\hline 60 & - & - & - & 16784 & 1296 & 748 \\
\hline 70 & - & - & - & 16488 & 577 & 333 \\
\hline 80 & - & - & - & 19648 & 812 & 469 \\
\hline 100 & - & - & - & 22981 & 207 & 118 \\
\hline
\end{tabular}

Table S7: Results of the binding experiments for selectivity testing for YOX and BAM. Wavelengths used: BAM: Em $340 \mathrm{~nm}$, Ex $450 \mathrm{~nm}$; YOX: Em 365 nm, Ex. 545 nm.

\begin{tabular}{|c|c|c|c|c|c|c|}
\hline $\begin{array}{c}\text { Particle } \\
\text { type }\end{array}$ & BAM & & & YOX & & \\
\hline Mass & $\begin{array}{c}\text { Mean } \\
\text { Summed } \\
\text { fluorescence }\end{array}$ & $\begin{array}{l}\text { Standard } \\
\text { Deviation }\end{array}$ & $\begin{array}{c}\text { Standard } \\
\text { error }\end{array}$ & $\begin{array}{c}\text { Mean } \\
\text { summed } \\
\text { fluorescence }\end{array}$ & $\begin{array}{l}\text { Standard } \\
\text { Deviation }\end{array}$ & $\begin{array}{c}\text { Standard } \\
\text { error }\end{array}$ \\
\hline APDMES & 926664 & 253474 & 146343 & 16576 & 624 & 360 \\
\hline FL464 & 782352 & 75910 & 43827 & 16797 & 637 & 368 \\
\hline $\mathrm{FL} 464 \mathrm{C} 1+\mathrm{C} 2 / \mathrm{A}$ & 710557 & 65748 & 37959 & 16027 & 580 & 335 \\
\hline FL464 C1/A & 640297 & 99265 & 57310 & 16621 & 1587 & 916 \\
\hline FL464 C2/A & 606024 & 82051 & 47372 & 15536 & 236 & 136 \\
\hline FL464 L/A & 783667 & 19948 & 115440 & 17573 & 2106 & 1216 \\
\hline FL464 P/A & 543000 & 25136 & 14512 & 16683 & 1315 & 759 \\
\hline
\end{tabular}

